\title{
Intrinsieke arbeidsoriëntatie en uitputting bij werknemers
}

\author{
Joris Van Ruysseveldt en Peter Smulders*
}

\begin{abstract}
Speelt een intrinsieke arbeidsoriëntatie een rol als persoonsgebonden hulpbron in het uitputtingsproces? Om die vraag te beantwoorden ontwikkelen we een onderzoeksmodel dat inzichten uit het Job Demands-Resources-model, het Vitaminemodel van Warr en de conservation of resources-theorie van Hobfoll integreert. De analyses zijn uitgevoerd op een omvangrijke, heterogene steekproef uit de Nederlandse beroepsbevolking (TNO Arbeidssituatie Survey, TAS 2002). De analyseresultaten bevestigen de hypothesen: een intrinsieke arbeidsoriëntatie hangt samen met minder uitputting, dempt de uitputtingsgevolgen van te hoge werkdruk, en versterkt het uitputtingsreducerende effect van veel autonomie en ontwikkelingsmogelijkheden. Op basis van deze onderzoeksresultaten besluiten we dat meer onderzoek naar de rol van deze en andere persoonsgebonden hulpbronnen in het uitputtingsproces wenselijk is.
\end{abstract}

Trefwoorden: persoonsgebonden hulpbronnen, JD-R-model, Vitaminemodel

\section{Inleiding}

In dit artikel onderzoeken we de rol die een intrinsieke arbeidsoriëntatie speelt in het uitputtings- of stressproces. Emotionele uitputting, een frequent bestudeerde negatieve werkuitkomst en een van de subdimensies van burn-out, is in dit onderzoek gehanteerd als indicator voor stress (Demerouti, Nachreiner, Bakker \& Schaufeli, 2001). ${ }^{1}$ Onder arbeidsoriëntaties verstaan we het belang of de waarde die werknemers toekennen aan specifieke aspecten van het werk (Van Hoof, Bruin, Schoemaker \& Vroom, 2002; Evers, Ybema \& Smulders, 2006: 39). ${ }^{2}$ Een intrinsieke arbeidsoriëntatie betekent dat de persoon veel belang hecht aan de inhoudelijke aspecten van het werk: zelfstandigheid, uitdaging, mogelijkheden tot zelfontplooiing. In contrast daarmee impliceert een extrinsieke arbeidsoriëntatie een grote gerichtheid op de opbrengsten van het werk, zoals inkomen, status, sociale contacten en gunstige vakantieregelingen. De werknemer werkt in de eerste plaats voor de knikkers, niet voor het plezier van het spel zelf. Intrinsieke en extrinsieke arbeidsoriëntaties sluiten elkaar overigens niet uit. Werknemers kunnen tezelfdertijd zowel de extrinsieke als intrinsieke werkaspecten waardevol vinden, of ze kunnen slechts een van deze werkaspecten belangrijk achten.

In Nederland is de rol van arbeidsoriëntaties in het ontstaan van werkgerelateerde stress nog maar weinig onderzocht. In buitenlandse onderzoeken is een significant negatief effect van intrinsieke arbeidsoriëntatie op stress gevonden: werknemers die een grote waarde toekennen aan het hebben van inhoudelijk interessant, uitdagend werk met veel persoonlijke ontwikkelingsmogelijkheden, weten beter om te gaan met veeleisend werk en zijn weerbaarder tegen de negatieve gevolgen van dergelijk stresserend werk (bijvoorbeeld Warr, 1994; Lu, 1999; Knoop, 2001; Baker, 2004; Van Steen-

* Joris Van Ruysseveldt is werkzaam bij de Open Universiteit Nederland. Correspondentieadres: Open Universiteit Nederland, Faculteit Psychologie, Postbus 2960, 6401 DL Heerlen, e-mail: joris.vanruysseveldt@ou.nl.

Peter Smulders is werkzaam bij TNO Kwaliteit van Leven. 
kiste, Neyrinck, Niemec, Soenens, De Witte \& Van den Broeck, 2007). Zo stelt Knoop (2001) vast dat (1) een intrinsieke arbeidsoriëntatie bij de werknemer samenhangt met een lager niveau van fysieke, emotionele en mentale stress, en (2) een extrinsieke arbeidsoriëntatie geen significant effect heeft op het stressniveau van werknemers. Hij concludeert dat in het gangbare stressonderzoek ten onrechte te weinig aandacht wordt besteed aan de rol van arbeidsoriëntaties als stress relievers. In een andere dan een werkcontext komt Baker (2004) tot vergelijkbare resultaten. Bij het bestuderen van de leerprestaties van universiteitsstudenten stelt ze vast dat intrinsiek georiënteerde studenten (sterke wens om te leren/weten) minder stress tijdens de studie ervaren, terwijl een extrinsieke studieoriëntatie geen significant effect heeft. Bourdeaud'hui \& Vanderhaeghe (2008) vinden voor een representatieve steekproef uit de Vlaamse beroepsbevolking een zwakke positieve correlatie tussen intrinsieke arbeidsoriëntatie en psychische vermoeidheid.

\section{Theoretische en praktische relevantie}

Het hier gerapporteerde onderzoek is om twee redenen relevant. Ten eerste is het $\mathrm{Ne}-$ derlandse onderzoek overwegend gericht op de bestudering van de effecten van arbeidsoriëntaties op positieve werkuitkomsten zoals arbeidstevredenheid of psychisch welbevinden (Boer, De Jonge \& Hamers, 2003; Achterberg, Houtman \& Jetten, 2003; Evers et al., 2006). Eerder uitzonderlijk is ook het effect op negatieve werkuitkomsten, zoals emotionele uitputting, bestudeerd (Taris \& Feij, 2001). Met dit onderzoek willen we het wetenschappelijke inzicht in de betekenis van een intrinsieke arbeidsoriëntatie voor het stressproces vergroten. Daarbij maken we gebruik van een omvangrijke, heterogene steekproef uit de Nederlandse beroepsbevolking, namelijk de TNO Arbeidssituatie Survey-databank (Smulders, Andries \& Otten, 2001).

Ten tweede stelt zich in dit verband een vraag met een meer algemeen-wetenschappelijke reikwijdte: levert de toevoeging van persoonsgebonden kenmerken aan de klassieke stressmodellen een theoretische en praktische meerwaarde op? De stressmodellen die in Nederland het frequentst worden toegepast, zoals het JD-C-model van Karasek (1979) en het JD-R-model (Demerouti et al., 2001), zijn te classificeren als 'werkkenmerken'-modellen: werkkenmerken vormen de belangrijkste predictoren voor stressverschijnselen en persoonsgebonden kenmerken - als ze al zijn opgenomen - spelen geen prominente rol in de verklaringsmechanismen. Ook uit onderzoek blijkt dat verschillen in stressniveau tussen werknemers hoofdzakelijk toe te schrijven zijn aan de kenmerken van het werk, en minder aan persoonsgebonden kenmerken (bijvoorbeeld Warr, 1994; Taris \& Feij, 2001; Achterberg et al., 2003; Xanthopoulou et al., 2007). Het wetenschappelijke 'nut' van de integratie van persoonsgebonden kenmerken in de 'werkkenmerken'modellen is daarmee nog onduidelijk.

Naast de genoemde bestaan er modellen waarin naast werkkenmerken ook persoonsgebonden kenmerken zijn opgenomen, maar waarvan de precieze implicaties voor de interventiepraktijk dubbelzinnig of niet eenduidig zijn, bijvoorbeeld de zogenoemde fitmodellen. Tot de meest geciteerde fitmodellen behoort het person-environment-fitmodel van French, Kaplan \& Harrison (1982). De fit of misfit tussen de persoon en zijn/haar werkomgeving bepaalt de mate van arbeidstevredenheid alsmede het optreden of uitblijven van spanningsverschijnselen. Een goede fit ontstaat wanneer de werknemer over voldoende vakbekwaamheid en vaardigheden beschikt om de gestelde werkeisen 
te realiseren. Een misfit tussen de competenties van de werknemer en diens werkeisen heeft een toename van spanningsverschijnselen tot gevolg. Nu stellen de uitgangspunten van de fitmodellen de interventiepraktijk voor een dilemma: als er een misfit optreedt tussen werk en persoon, moeten interventies zich dan richten op het werk of op de persoon, of op beide? Een voorbeeld uit het onderzoek van Boer et al. (2003) illustreert dit dilemma. Zij stellen vast dat werknemers in de zorgsector met een lage behoefte aan autonomie en een hoge autonomie minder tevreden zijn dan werknemers met een hoge behoefte aan autonomie. Ze zijn zelfs minder tevreden dan werknemers met een lage behoefte aan autonomie en weinig autonomie. Een teveel aan autonomie (in vergelijking met hun behoefte daaraan) maakt werknemers blijkbaar ontevredener. Moet dan de autonomie voor deze groep werknemers verlaagd worden ten einde een goede fit te realiseren? Of dient hun behoefte aan autonomie gestimuleerd te worden? En hoe dan? Een alternatieve, en vaak gesuggereerde, interventie naar aanleiding van dergelijke onderzoeksresultaten is dat het probleem van de kwaliteit van de arbeid op de werkvloer wordt teruggebracht tot een selectieprobleem waarbij werkgevers ernaar streven de bij het werk meest passende persoon te vinden. Ook Boer et al. (2003: 233) trekken uit hun onderzoek een conclusie die wijst op het gevaar om vanuit de fitgedachte de kwaliteit van de arbeid te reduceren tot een selectieprobleem: ' ... bij de aanstelling van nieuw personeel zou men rekening moeten houden met bij de functie-inhoud passende persoonskenmerken en tevens moeten proberen onnodige "mismatches" te voorkomen. Kortom, naast allerlei werkgerichte maatregelen blijft individueel maatwerk noodzakelijk.'

Nu zijn recent in de traditie van het JD-R-model veelbelovende ontwikkelingen gaande, die zowel in theoretisch als in praktisch opzicht vorderingen toelaten en die aangrijpingspunten bieden voor het overstijgen van het beschreven interventiedilemma. Op die ontwikkelingen wordt in dit onderzoek voortgeborduurd. Daarbij staat de vraag centraal of bepaalde persoonsgebonden kenmerken zijn te beschouwen als hulpbronnen. Zoals een werknemer in de functie en organisatie bepaalde hulpbronnen (bijvoorbeeld leermogelijkheden) ter beschikking heeft om de werkdoelen te realiseren, zo ook kan men zich afvragen of bepaalde van diens kenmerken (bijvoorbeeld leergierigheid) niet als hulpbron fungeren. Dergelijke kenmerken zouden de werknemer dan beter toelaten de problemen in het werk te beheersen en de negatieve gevolgen ervan onder controle te houden. Vanuit een dergelijk perspectief krijgt wetenschappelijk onderzoek op dit domein ook meer praktische relevantie. Als persoonsgebonden kenmerken worden opgespoord die het karakter hebben van een hulpbron, kunnen overheid, organisaties en individuen ook meer gericht ingrepen plannen om dergelijke kenmerken verder te ontwikkelen.

Voor dit onderzoeksdoel ontwikkelen we een onderzoeksmodel waarin inzichten uit het JD-R-model (Demerouti et al., 2001), het Vitaminemodel van Warr (1994) en de conservation of resources-theorie (COR) van Hobfoll (2002) zijn geïntegreerd. In de volgende paragraaf behandelen we kort de theoretische uitgangspunten van deze modellen. 


\section{Werkkenmerken, persoonsgebonden kenmerken en stress: theoretische beschouwingen}

Ons onderzoeksmodel steunt in hoge mate op het JD-R-model (Bakker, Schaufeli \& Demerouti, 1999; Demerouti et al., 2001). Een basisassumptie van dat model is dat, hoewel elke beroepsgroep wordt geconfronteerd met specifieke, beroeps- of functieeigen taakkenmerken en risicofactoren, deze taakkenmerken en risicofactoren steeds onder te brengen zijn in twee categorieën. Job demands of werkeisen omvatten alle fysieke, sociale of organisationele aspecten van het werk die een volgehouden fysieke of mentale inspanning vereisen en die om die reden verbonden zijn met specifieke fysiologische en psychologische kosten voor de werknemer (bijvoorbeeld uitputting). Job resources of hulpbronnen omvatten alle fysieke, psychologische, sociale of organisationele aspecten van het werk die (a) bijdragen aan het realiseren van de taakdoelstellingen, (b) de fysiologische en psychologische kosten verbonden met de aanwezige werkeisen reduceren, en (c) persoonlijke groei en ontwikkeling stimuleren. De werkeisen en hulpbronnen hangen elk samen met specifieke werkuitkomsten, en dat als gevolg van het optreden van twee parallelle processen: een Energetic Process en een Motivational Process (Schaufeli \& Bakker, 2004: 297-299). In het eerste proces leiden de veeleisende aspecten van het werk tot een voortdurende aantasting van de energiereserves van de taakuitvoerder, en daarmee op de lange duur tot chronische vermoeidheid en uitputting. Het tweede proces is motivationeel van aard: hulpbronnen kunnen intrinsiek motiveren doordat ze de werknemer in staat stellen diens behoeften aan persoonlijke groei en ontwikkeling te stimuleren en te realiseren. Maar ze spelen daarnaast ook een extrinsiek motiverende rol omdat ze het de werknemer mogelijk maken de taakdoelstellingen te realiseren. Het effect van dit proces op de werknemer is een positieve psychische toestand die bevlogenheid wordt genoemd. Ten slotte veronderstelt het JD-R-model dat allerlei werkeisen en hulpbronnen kunnen interacteren en zo tot verminderde uitputting en verhoogde motivatie kunnen leiden. Het JD-R-model is meermaals in empirisch onderzoek getoetst (Demerouti et al., 2001; Schaufeli \& Bakker, 2004; Van Ruysseveldt, 2006; Bakker \& Demerouti, 2007). De plausibiliteit van de veronderstellingen in het JD-R-model staat inmiddels buiten discussie: werkeisen vormen de belangrijkste predictoren van negatieve werkuitkomsten zoals emotionele uitputting; hulpbronnen zijn dan weer de belangrijkste predictoren van positieve werkuitkomsten zoals bevlogenheid (Xanthopoulou et al., 2007). Onze eerste hypothese luidt dan ook:

H1: De werkeisen hebben elk een significant positief hoofdeffect, en de organisatieen taakgerelateerde hulpbronnen (O-HB) hebben elk een significant negatief hoofdeffect op de emotionele uitputting.

De laatste jaren is de aandacht voor het belang en de rol van persoonsgebonden kenmerken in het JD-R-model sterk toegenomen (Bakker \& Demerouti, 2007). Zo ontwikkelen en toetsen Xanthopoulou et al. (2007) een uitgebreider model waarin naast werkeisen en hulpbronnen ook personal resources zijn opgenomen. Ze baseren zich daarbij op de conservation of resources-theorie van Hobfoll (2002). Naast objecten, omstandigheden en energiebronnen beschouwt Hobfoll (2002: 307) ook persoonsgebonden kenmerken als resources. Dat zijn entiteiten die door de eigenaar worden gewaardeerd om zichzelf (inherente waarde) of als middel in het realiseren van gewaardeerde doelen. Ten aanzien van deze resources gelden de volgende twee assumpties: (1) personen investeren in het verwerven van resources omdat deze hen in staat stellen om te gaan met bedreigende omstandigheden en hen beschermen tegen de negatieve 
effecten van die omstandigheden; (2) personen streven er niet alleen naar hun resources te beschermen, maar ook nieuwe te accumuleren (Hobfoll, 2002: 312). Xanthopoulou et al. (2007: 123-124) omschrijven personal resources (PR) in het verlengde hiervan als persoonsgebonden aspecten die in het algemeen positief gekoppeld zijn aan veerkracht/ herstellingsvermogen, en die het vermogen van een persoon bevorderen om diens omgeving succesvol te beheersen en te beïnvloeden.

In ons onderzoek beschouwen we een intrinsieke arbeidsoriëntatie als een persoonsgebonden hulpbron. In lijn met de voorafgaande theoretische assumpties en met inzichten uit eerder onderzoek (o.a. Lu, 1999; Knoop, 2001; Baker, 2004) veronderstellen we dat persoonsgebonden hulpbronnen de werknemer beter in staat stellen om te gaan met problemen in zijn of haar werkomgeving zodat de negatieve gevolgen ervan uitblijven of beheersbaar blijven. Onze tweede hypothese luidt:

H2: De mate van intrinsieke arbeidsoriëntatie heeft een significant negatief hoofdeffect op de emotionele uitputting. Naarmate werknemers sterker intrinsiek georiënteerd zijn, daalt de emotionele uitputting.

Xanthopoulou et al. (2007: 124-125) veronderstellen dat PR een verschillende rol spelen in de eerder beschreven energetische en motivationele processen. In het energetische of stressproces hebben persoonsgebonden hulpbronnen een rol als moderator in de relatie tussen werkeisen en uitputtingsverschijnselen. Deze assumptie is conform het derde mechanisme van resources van Hobfoll (2002: 318): personen met veel hulpbronnen zijn beter in staat problemen verbonden met stressvolle gebeurtenissen op te lossen of te ondervangen, aangezien de kans toeneemt dat zij over de meest geëigende resources beschikken om de gestelde problemen op te lossen, of over resources beschikken die hen in staat stellen die meest geëigende resources te verwerven. PR hebben in het JD-R-model een vergelijkbaar effect als de job resources. Naarmate de werknemer meer beschikt over dergelijke hulpbronnen, neemt zijn of haar beheersingsvermogen over de omgeving toe. Daardoor kan hij of zij effectiever omgaan met veeleisende omstandigheden en blijven de negatieve stressgevolgen daarvan beperkter.

Xanthopoulou et al. (2007) toetsen deze veronderstelling bij een steekproef van 714 Nederlandse werknemers van een elektronicabedrijf. De door hen onderzochte PR zijn algemene self-efficacy, self-esteem en optimisme. Ze vinden echter geen empirische evidentie voor een modererend effect van deze PR op de relatie tussen werkeisen en emotionele uitputting. De onderzoekers wijten dat onder meer aan de homogeniteit van hun steekproef. Die kent een oververtegenwoordiging van hooggeschoolden, wat aanleiding kan zijn voor een restriction of range in de geanalyseerde variabelen. De in ons onderzoek gebruikte dataset betreft een omvangrijke, heterogene steekproef uit de Nederlandse beroepsbevolking en is om die reden beter geschikt voor het toetsen van het veronderstelde moderatie-effect.

In ander onderzoek is wel empirische evidentie gevonden voor de modererende rol van persoonsgebonden kenmerken in het stressproces. Zo vindt Lu (1999) in een Chinees onderzoek een significant modererend effect van intrinsieke oriëntaties op de relatie tussen (gebrek aan) autonomie en angstigheid en van extrinsieke oriëntaties op de relatie tussen werkdruk en psychosomatische klachten. En Houkes, Janssen, De Jonge \& Bakker (2003) vinden in een longitudinaal onderzoek onder leerkrachten en bankmedewerkers naast een significant hoofdeffect ook een significant modererend 
effect van een persoonsgebonden kenmerk (negatieve affectiviteit) op de relatie tussen werkdruk en uitputting. Het effect van werkdruk op uitputting is sterker voor werknemers met een hoge negatieve affectiviteit.

Er bestaan dus zowel theoretische argumenten als empirische indicaties voor het optreden van een modererend effect van (intrinsieke) arbeidsoriëntaties op de relatie tussen werkeisen en stressindicatoren. Op grond daarvan formuleren we de derde hypothese als volgt:

H3: Een intrinsieke arbeidsoriëntatie buffert het positieve hoofdeffect van de werkeisen op de emotionele uitputting. Naarmate een sterkere intrinsieke arbeidsoriëntatie aanwezig is, leidt een toename in de werkeisen niet of in mindere mate tot een toename van de emotionele uitputting.

Het wekt enigszins verbazing dat Xanthopoulou et al. (2007) op theoretische gronden niet ook een modererend effect van PR op de relatie tussen hulpbronnen en uitputting veronderstellen. Als $\mathrm{PR}$ voluit worden geconceptualiseerd als resources, naar analogie met job resources, dan zou kunnen worden verondersteld dat in situaties waarin werknemers beide soorten resources in hoge mate beschikbaar hebben, het gezamenlijke effect op uitputting sterker is (een multiplicatieve functie volgt) dan het effect van elk afzonderlijk (additieve functie). In het Vitaminemodel van Warr (1994) wordt een dergelijke veronderstelling gepostuleerd. Dat model voor de verklaring van werkgerelateerde mentale gezondheidsproblemen gaat ervan uit dat werkkenmerken een vergelijkbaar effect hebben op de mentale gezondheid als vitamines op de fysieke gezondheid. Sommige werkkenmerken, zoals loon en zekerheid, hebben een effect op mentale gezondheid dat vergelijkbaar is met de werking van vitamines $C$ en $\mathrm{E}$ : naarmate ze meer aanwezig zijn, stijgt de mentale gezondheid, maar boven een bepaald niveau is er geen effect meer. Andere werkkenmerken, zoals autonomie, afwisseling in het werk en vaardigheidsbenutting, hebben een effect vergelijkbaar met de werking van de vitamines A en D: naarmate ze meer aanwezig zijn, stijgt de mentale gezondheid, maar boven een bepaald niveau verandert dat positieve effect in een negatief effect (Warr, 1994: 88).

Naast deze werkkenmerken integreert Warr in zijn model ook enkele individuele kenmerken, waaronder vaardigheden en werkwaarden (= arbeidsoriëntaties) (Evers et al., 2006: 38). Deze persoonsgebonden kenmerken beïnvloeden de relatie tussen de werkkenmerken en mentale gezondheid, waarbij Warr een dergelijk effect vooral verwacht van de werkwaarden en vaardigheden. Warr formuleert in dit verband het principe van de matching characteristics (1994: 90): als een bepaald werkkenmerk in het werk aanwezig is, zal het effect van dat kenmerk op de mentale gezondheid sterker zijn naarmate de werknemer veel belang hecht aan de bijpassende werkwaarde. Bijvoorbeeld zal veel afwisseling in het werk sterker samenhangen met een goede mentale gezondheid wanneer de werknemer een hoge waarde hecht aan afwisseling in het werk. Omgekeerd leidt een geringe afwisseling in het werk tot een sterkere daling in de mentale gezondheid wanneer werknemers veel waarde hechten aan dat werkkenmerk.

Het vitaminemodel (of onderdelen daarvan) is meermaals toegepast in Nederlands onderzoek, maar dan meestal voor het verklaren van positieve werkuitkomsten als arbeidstevredenheid. Zo onderzoeken Evers et al. (2006) in een representatieve steekproef uit de Nederlandse beroepsbevolking voor zeven werkkenmerken of een 
goede fit met de bijhorende werkwaarde samenhangt met een hogere arbeidstevredenheid. Zij vinden in (slechts) drie van de zeven gevallen dat de combinatie van een werkkenmerk en de bijhorende werkwaarde leidt tot een significant hogere arbeidstevredenheid: dat geldt voor de combinaties complex werk/belang interessant werk, afwisseling/belang afwisselend werk, en baanzekerheid/belang zekerheid. Ook in ander Nederlands onderzoek (Taris \& Feij, 2001; Boer et al., 2003) is voor het Vitaminemodel slechts gedeeltelijk empirische evidentie gevonden.

Het moderatie-effect dat in ons onderzoek wordt verondersteld, wijkt echter qua verloop enigszins af van Warrs principe van de matching characteristics. We gaan er conform de COR-theorie van uit dat wanneer een taak- en organisatiegerelateerde hulpbron (bijvoorbeeld autonomie in het werk) slechts in geringe mate aanwezig is, de aanwezigheid van een sterke intrinsieke arbeidsoriëntatie niet leidt tot een hogere emotionele uitputting, zoals Warr bij een mismatch veronderstelt. De achterliggende reden is dat een intrinsieke arbeidsoriëntatie op zich al een hulpbron is, zij het een persoonsgebonden, en dat het negatieve hoofdeffect van een hoge aanwezigheid van die hulpbron op uitputting ook in voldoende mate optreedt bij een geringe aanwezigheid van de taaken organisatiegerelateerde hulpbronnen. Het modererend effect treedt vooral op wanneer taak- en organisatiegerelateerde hulpbronnen in hoge mate aanwezig zijn. In dat geval daalt de uitputting bij alle werknemers, maar veel sterker bij werknemers die intrinsiek georiënteerd zijn. Een intrinsieke arbeidsoriëntatie heeft dus vooral een versterkend effect op de daling van uitputting bij een toename van de taak- en organisatiegerelateerde hulpbronnen. Onze vierde hypothese luidt dan:

H4: Een intrinsieke arbeidsoriëntatie versterkt het negatieve hoofdeffect van de hulpbronnen op de emotionele uitputting: bij een hogere intrinsieke arbeidsoriëntatie leidt een toename in de hulpbronnen tot een sterkere daling van de emotionele uitputting.

Stressmodellen die werk- en persoonsgebonden kenmerken integreren, roepen automatisch de vraag op naar de onderlinge samenhang tussen deze twee soorten kenmerken. Wat beïnvloedt wat? Beïnvloeden arbeidsoriëntaties het werk dat men uiteindelijk zal gaan verrichten (zie Lofquist \& Dawis, 1969; Warr, 1994; Judge et al., 2000)? Of bepaalt het werk wat werknemers aantrekkelijk en waardevol vinden (de aanpassingsthese, zie Berting \& De Sitter, 1969, 1971; Achterberg, Houtman \& Jetten, 2003)? Hoewel het in het bestek van dit artikel niet mogelijk is hier uitgebreid op in te gaan, willen we deze kwestie ook niet helemaal onbehandeld laten.

Een aantal onderzoekers rapporteert het optreden van mediatie-effecten tussen werkkenmerken en persoonsgebonden kenmerken op de werkuitkomsten. Warr bijvoorbeeld poneert dat werkwaarden een invloed hebben op de werkkenmerken, meer bepaald als gevolg van processen van zelfselectie: werknemers met bepaalde werkwaarden zullen geneigd zijn werk te zoeken dat past bij hun waarden (de zelfselectiethese) (Evers et al., 2006: 38). Voor een dergelijk mediatie-effect is ook empirische evidentie gevonden door Judge en collega's (Judge, Locke, Durham \& Kluger, 1998; Judge, Bono \& Locke, 2000). Omgekeerd stellen Xanthopoulou et al. (2007) vast dat de personal resources de relatie tussen job resources en emotionele uitputting mediëren. Werknemers die opereren in een werkomgeving met veel hulpbronnen, blijken bekwamer in het vervullen van hun taken zonder uitzonderlijk veel inspanning te moeten leveren, zodat ze ook niet zo snel uitgeput geraken. 
Op grond van dergelijke, tegengestelde onderzoeksresultaten is de genoemde theoretische discussie niet te beslechten. In ons onderzoek gaan we wel na of dergelijke mediatie-effecten in de data zijn terug te vinden. Maar in theoretisch opzicht sluiten we aan bij Kohn \& Schooler (1982), die de verhouding tussen persoonsgebonden kenmerken en werkkenmerken als wederzijds interpreteren: zo kunnen personen bijvoorbeeld als gevolg van sterke leerervaringen in concrete werkcontexten een positief zelfbeeld ontwikkelen, waardoor ze op hun beurt meer ondersteunende en uitdagende omgevingen tot stand brengen (het Learning-Generalization Model). De wederkerigheid in de relatie tussen job en personal resources wordt ook gepostuleerd in Hobfolls (2002: 318) 'vijfde' mechanisme: resources zijn met elkaar verbonden, in die zin dat er een tendens bestaat om de beschikbare resources te benutten voor het verwerven van nieuwe, zodat de werknemer uiteindelijk resource caravans opbouwt. De beschikbare job resources, bijvoorbeeld leermogelijkheden in het werk, kunnen worden benut voor het verwerven van personal resources, bijvoorbeeld een positief zelfbeeld (de ontwikkelingsthese). En omgekeerd kunnen bepaalde personal resources, bijvoorbeeld een intrinsieke arbeidsoriëntatie, worden ingezet voor het effectiever benutten van job resources, bijvoorbeeld autonomie in het werk (de activeringsthese). We veronderstellen dus een positieve samenhang tussen beide soorten hulpbronnen.

\section{Onderzoeksmodel}

De veronderstelde verbanden tussen intrinsieke arbeidsoriëntatie, werkkenmerken en werkuitkomsten zijn grafisch weergegeven in figuur 1 . De basisassumptie luidt dat bepaalde persoonsgebonden kenmerken dezelfde uitwerking hebben op de werkeisen en hun effect op uitputting, als de taak- en organisatiegerelateerde hulpbronnen uit het JD-R-model. Daarmee brengen we een nader onderscheid aan tussen de hulpbronnen die organisatie- en taakgerelateerd zijn (bijvoorbeeld autonomie, leermogelijkheden) en hulpbronnen die met de persoon zelf verbonden zijn (bijvoorbeeld een positief zelfbeeld, het competentieniveau). De eerste categorie duiden we aan als O-HB, de tweede als P-HB. We hanteren daarbij een definitie voor P-HB die licht afwijkt van die van Xanthopoulou et al. (2007). Deze begripsomschrijving is opgebouwd naar analogie met die van de O-HB uit het JD-R-model (Demerouti et al., 2001). Persoonsgebonden hulpbronnen omvatten dan al die kenmerken van de werkende persoon die (a) bijdragen aan het realiseren van de taakdoelstellingen, (b) de fysiologische en psychologische kosten verbonden met de aanwezige werkeisen reduceren, en (c) persoonlijke groei en ontwikkeling stimuleren.

In lijn met voornoemde definitie is een persoonsgebonden kenmerk slechts als P-HB te kwalificeren indien dat kenmerk (1) een negatief effect heeft op uitputting, (2) het positieve effect van werkeisen op uitputting verzwakt (zoals de O-HB dat doen) en (3) het negatieve effect van $\mathrm{O}-\mathrm{HB}$ op uitputting versterkt. Deze 'strenge' omschrijving van P-HB kent een sterk instrumentele achtergrond. We zijn niet louter om intellectuele redenen geïnteresseerd in de rol van persoonsgebonden kenmerken in het stressproces, maar streven naar een model met een inherente relevantie voor de interventiepraktijk. 
Figuur I Het onderzoeksmodel

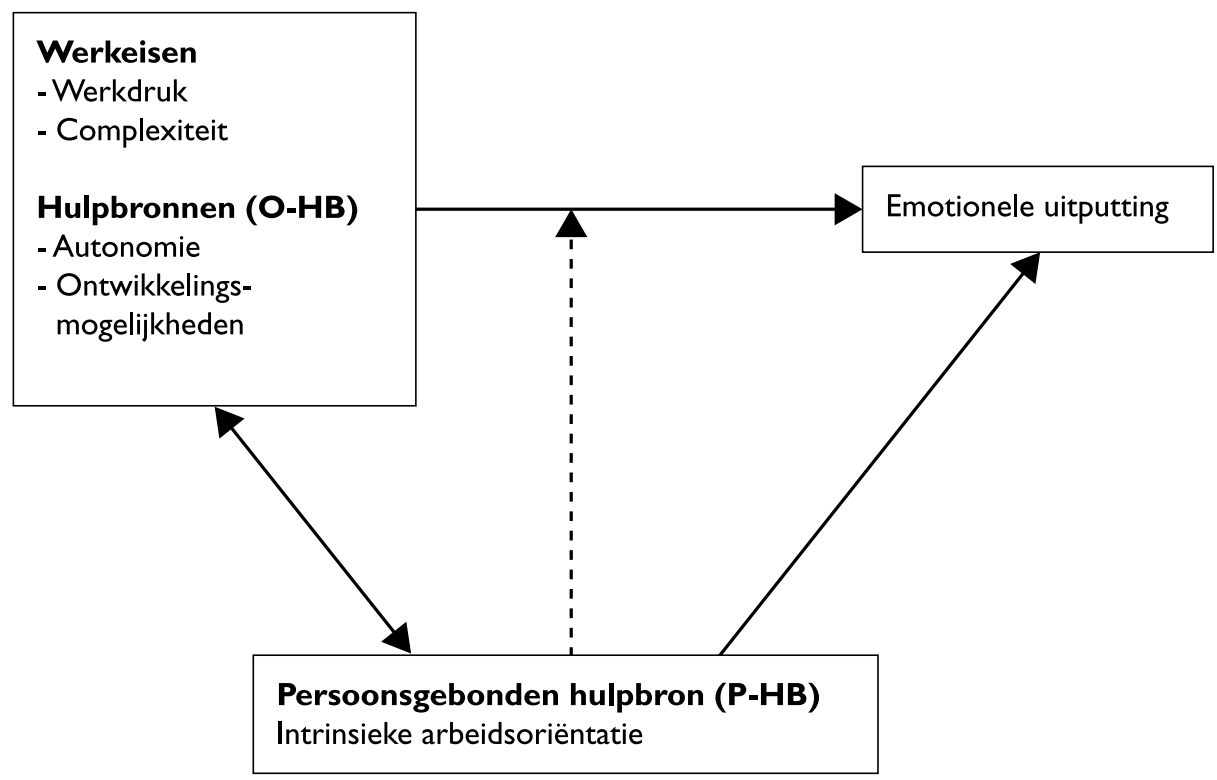

In het onderzoek zijn twee werkeisen (werkdruk en complexiteit van het werk) en twee $\mathrm{O}-\mathrm{HB}$ (autonomie en ontwikkelingsmogelijkheden) betrokken. Uit onderzoek blijkt dat deze vier werkkenmerken tot de belangrijkste predictoren van uitputting behoren (Van Ruysseveldt, 2006; Bakker \& Demerouti, 2007; Xanthopoulou et al., 2007; Van Ruysseveldt, Smulders \& Taverniers, 2008). Ze zijn bovendien sterk taakgerelateerd, in tegenstelling tot bijvoorbeeld werk-thuis-interferentie of sociale steun. Omdat we geïnteresseerd zijn in de rol van een intrinsieke arbeidsoriëntatie in het stressproces, is een gerichtheid op de taakinhoudelijke aspecten van het werk te verkiezen.

Het JD-R-model voorspelt dat een toename in elk van de twee werkeisen een toename van de emotionele uitputting tot gevolg heeft, en dat een toename in elk van de twee hulpbronnen samenhangt met een afname van de emotionele uitputting (zie H1). Uit de onderzoeksliteratuur blijkt bovendien dat deze werkkenmerken samen een aanzienlijk grotere bijdrage leveren aan de verklaarde variantie dan persoonsgebonden kenmerken (Warr, 1994; Taris \& Feij, 2001; Achterberg et al., 2003; Xanthopoulou et al., 2007).

De kernvraag in het onderzoek is of een intrinsieke arbeidsoriëntatie zich 'gedraagt' als een P-HB, volgens de hiervoor beschreven definitie. Dat is slechts het geval indien een intrinsieke arbeidsoriëntatie (a) een negatief hoofdeffect heeft op uitputting (H2), (b) het positieve effect van werkdruk en complexiteit op uitputting verzwakt (H3) en (c) het negatieve effect van autonomie en ontwikkelingsmogelijkheden op uitputting versterkt (H4).

Hoewel we op dat gebied geen veronderstellingen formuleren of aannames maken, is naast de intrinsieke arbeidsoriëntatie ook de extrinsieke arbeidsoriëntatie in de analyse opgenomen. Uit eerder onderzoek (bijvoorbeeld Van Steenkiste et al., 2007: 260) blijkt namelijk dat beide oriëntaties onderling (matig) positief samenhangen. Personen 
kunnen zowel sterk intrinsiek als sterk extrinsiek georiënteerd zijn. De ene oriëntatie sluit de andere niet uit. Maar deze bevinding kan ook een artefact zijn van de meetmethode. Het is mogelijk dat respondenten die werk in het algemeen belangrijk vinden, zowel intrinsieke als extrinsieke werkaspecten hoog waarderen, niet omwille van die aspecten zelf, maar omdat ze allemaal verbonden zijn met werk. In dat geval worden geen afzonderlijke arbeidsoriëntaties gemeten, maar een ander construct, zoals werkcentraliteit (zie Van Hoof et al., 2002). Om de mate van intrinsieke arbeidsoriëntatie zo correct of zuiver mogelijk weer te geven, is het om methodologische redenen belangrijk bij het analyseren van een intrinsieke arbeidsoriëntatie te controleren voor extrinsieke arbeidsoriëntatie. Bovendien kan tussen beide arbeidsoriëntaties een interactieeffect optreden. Het is niet uit te sluiten dat de intrinsieke arbeidsoriëntatie alleen leidt tot minder emotionele uitputting wanneer de extrinsieke arbeidsoriëntatie laag is (Van Steenkiste et al., 2007).

\section{Methode}

\section{Dataverzameling en steekproef}

De TNO Arbeidssituatie Survey (TAS) is een schriftelijke cross-sectionele survey die iedere twee jaar de arbeidssituatie in een toevalssteekproef uit de Nederlandse beroepsbevolking meet (Smulders et al., 2001). Omdat vrouwen en jongeren ondervertegenwoordigd waren, is een aanvullende steekproeftrekking gedaan bij deze groepen (Evers, Ybema \& Smulders, 2006: 42). In 2002 omvatte de netto steekproef 4009 personen (respons van $45 \%$ ).

\section{Meetinstrumenten (schalen)}

Emotionele uitputting betreft een van de dimensies van burn-out en indiceert de mate waarin als gevolg van het werk spanningsverschijnselen optreden bij de werknemer. Emotionele uitputting is gemeten aan de hand van de vijf items van de Utrechtse Burnout Schaal UBOS (Schaufeli \& Van Dierendonk, 2000). Antwoorden kan op een zevenpuntsschaal gaande van 'nooit' tot 'dagelijks'.

De werkkenmerken zijn gemeten op vierpuntsschalen variërend van 'nooit' (1) tot 'altijd' (4). Werkdruk is gemeten met vijf items die een indicatie geven van de kwantitatieve werkdruk. De interne consistentie (Cronbachs alpha) van de gebruikte schalen zijn gerapporteerd op de diagonale as in tabel 1. Complexiteit van het werk meet aan de hand van vijf items de kwalitatieve werkdruk, meer bepaald het beslag dat het werk geestelijk legt op de werknemer. De vragen zijn ontleend aan Houtman, Goudswaard, Dhondt, Van der Grinten, Hildebrandt \& Kompier (1995). Autonomie in het werk is gemeten aan de hand van vijf items die een variant zijn op de decision latitude-vragen uit de Job Content Questionnaire van Karasek. Ze zijn bewerkt en vertaald door Goudswaard, Dhondt \& Kraan (1998). De ontwikkelingsmogelijkheden zijn gemeten met vijf items die de mate indiceren waarin het werk aansluit bij ontwikkelde kennis en vaardigheden en de mate waarin de taakuitvoerder wordt geprikkeld om zich in het werk verder te ontwikkelen (denk aan skill discretion bij Karasek) (Houtman et al., 1995; Goudswaard et al., 1998). 


\section{Intrinsieke en extrinsieke arbeidsoriëntaties}

In de TAS 2002 is de respondenten gevraagd aan te geven op een vierpuntsschaal, variërend van 'niet erg belangrijk' (1) tot 'heel erg belangrijk' (4), in welke mate zij bepaalde aspecten van het werk in het algemeen waarderen. Intrinsieke arbeidsoriëntatie is gemeten als de mate waarin de werknemer de volgende aspecten van het werk in hoge mate waardeert: zelfstandigheid, variatie, leer- en groeimogelijkheden, interessant werk, iets bereiken en werk dat past bij de kennis (interne consistentie $=.74$ ). Extrinsieke arbeidsoriëntatie is gemeten als het belang dat de werknemer hecht aan volgende aspecten van het werk: goede collega's en leiding, goede beloning en arbeidsomstandigheden, zekerheid en geschikte werktijden (interne consistentie $=.77$ ).

\section{Controlevariabelen}

Bepaalde sociaaldemografische kenmerken hebben een significant hoofdeffect op zowel de arbeidsoriëntaties als de emotionele uitputting. In de analyses is daarom steeds gecontroleerd voor geslacht, leeftijd, onderwijsniveau en contractuele wekelijkse arbeidsduur.

\section{Analyses}

Eerst zijn betrouwbaarheids- en correlatieanalyses uitgevoerd. De hypothesen zijn getoetst middels hiërarchische regressieanalyses (SPSS, versie 14). De interactietermen zijn berekend als het product van de gestandaardiseerde schaalscores. Tevens is gekeken naar het optreden van eventuele mediatie-effecten.

\section{Resultaten}

Uit tabel 1 blijkt dat intrinsieke en extrinsieke arbeidsoriëntaties onderling een positieve samenhang $(.30, \mathrm{p}<.01)$ vertonen. Werknemers met een intrinsieke arbeidsoriëntatie hanteren vaak ook een extrinsieke arbeidsoriëntatie, en omgekeerd. Bovendien hangt een intrinsieke arbeidsoriëntatie significant positief samen met autonomie en ontwikkelingsmogelijkheden, wat een indicatie is voor het bestaan van resource caravans (Hobfoll, 2002).

Tabel I Correlatiematrix (Crohnbachs alphawaarden tussen haakjes)

\begin{tabular}{lccccccc}
\hline & $\mathbf{I}$ & $\mathbf{2}$ & $\mathbf{3}$ & $\mathbf{4}$ & $\mathbf{5}$ & $\mathbf{6}$ & $\mathbf{7}$ \\
\hline I. Werkdruk & $(.82)$ & & & & & & \\
2. Complexiteit van het werk & $.40^{* *}$ & $(.8 \mathrm{I})$ & & & & & \\
3. Autonomie & $.05^{* *}$ & $.21^{* *}$ & $(.86)$ & & & & \\
4. Ontwikkelingsmogelijkheden & $.24^{* *}$ & $.61^{* *}$ & $.31^{* *}$ & $(.80)$ & & & \\
5. Intrinsieke arbeidsoriëntatie & $.15^{* *}$ & $.29^{* *}$ & $.20^{* *}$ & $.34^{* *}$ & $(.74)$ & & \\
6. Extrinsieke arbeidsoriëntatie & $\mathrm{ns}$ & $.03^{*}$ & $-.11^{* *}$ & $\mathrm{~ns}$ & $.30^{* *}$ & $(.77)$ & \\
7. Emotionele uitputting & $.33^{* *}$ & $.13^{* *}$ & $-.10^{* *}$ & $\mathrm{~ns}$ & $\mathrm{~ns}$ & $\mathrm{~ns}$ & $(.89)$ \\
\hline
\end{tabular}

$* * \mathrm{p}<.01$ of minder, $* \mathrm{p}<.05$ of minder

Het niveau van intrinsieke arbeidsoriëntatie hangt samen met enkele sociaaldemografische kenmerken. In een multipele regressieanalyse met intrinsieke arbeidsoriëntatie als afhankelijke blijkt dat jongeren een sterkere intrinsieke arbeidsoriëntatie hebben dan ouderen $(\beta=-.10, \mathrm{p}<.01)$, dat de intrinsieke arbeidsoriëntatie sterk toeneemt 
naarmate het opleidingsniveau stijgt $(~(=.21, \mathrm{p}<.01)$ en sterker wordt naarmate de contractuele wekelijkse arbeidsduur toeneemt $(\Omega=.19, \mathrm{p}<.01)$. Geslacht heeft geen significant hoofdeffect op de intrinsieke arbeidsoriëntatie. Een extrinsieke arbeidsoriëntatie heeft een sterk significant positief hoofdeffect op de mate waarin men een intrinsieke arbeidsoriëntatie hanteert $(B=.38, \mathrm{p}<.01)$. De totale verklaarde variantie bedraagt $17 \%$. Omdat de meeste sociaaldemografische kenmerken ook een significante samenhang vertonen met emotionele uitputting (zie tabel 2), is het wenselijk bij het bestuderen van het effect van intrinsieke arbeidsoriëntatie op uitputting daarvoor te controleren.

Tabel 2 Hiërarchische regressieanalyse met emotionele uitputting als afhankelijke: mediatie-effect (TAS 2002).

\begin{tabular}{lcc}
\hline & \multicolumn{2}{c}{ Emotionele uitputting } \\
& Model I & Model 2 \\
\hline Onderwijsniveau & $.07^{* *}$ & $.05^{* *}$ \\
Leeftijd & $\mathrm{ns}$ & $\mathrm{ns}$ \\
Aantal contracturen & $.13^{* *}$ & $.10^{* *}$ \\
Geslacht & $.05^{* *}$ & $\mathrm{~ns}$ \\
Intrinsieke oriëntatie & $.05^{* *}$ & $.04^{* *}$ \\
Extrinsieke oriëntatie & $.04^{*}$ & $\mathrm{~ns}$ \\
Intrinsiek x extrinsiek & $\mathrm{ns}$ & $\mathrm{ns}$ \\
Werkdruk & & $.3 I^{* *}$ \\
Complexiteit & & $.09 * *$ \\
Autonomie & & $.11^{* *}$ \\
Ontwikkelingsmogelijkheden & & $.14^{* *}$ \\
Constante & & 2.60 \\
Model & 2.64 & 55.13 \\
Totaal verklaarde variantie & 9.77 & .141 \\
\hline
\end{tabular}

$* * \mathrm{p}<.01, * \mathrm{p}<.05$

Alvorens de andere hypothesen te toetsen moet eerst duidelijker zijn of er al dan niet een direct effect is van intrinsieke arbeidsoriëntatie op uitputting (hypothese 2). In tabel 2 zijn de resultaten van een multipele regressieanalyse weergegeven met uitputting als afhankelijke. In model 1 zijn naast de sociaaldemografische kenmerken ook de hoofdeffecten van intrinsieke en extrinsieke arbeidsoriëntatie alsmede hun interactieterm opgenomen. In tegenstelling tot de correlatie in tabel 1 blijkt de regressiecoëfficiënt van intrinsieke arbeidsoriëntatie in model 1 wel significant. Gecontroleerd voor de sociaaldemografische kenmerken raken werknemers minder snel uitgeput naarmate ze sterker intrinsiek georiënteerd zijn ( $(=-.05, \mathrm{p}<.01)$. De bijdrage aan de totale verklaarde variantie in uitputting van de variabelen uit model 1 is erg bescheiden (Adj. $\mathrm{R}^{2}=.02$ ). Het interactie-effect tussen beide soorten arbeidsoriëntaties is niet significant.

Aan de voorwaarden voor het verkennen van eventuele mediatie-effecten is voldaan. Zowel de werkkenmerken als de beide arbeidsoriëntaties vertonen een significante samenhang met de afhankelijke variabele, terwijl de werkkenmerken en de intrinsieke arbeidsoriëntatie onderling significant samenhangen. 
In model 2 (zie tabel 2) zijn naast de sociaaldemografische kenmerken en de beide arbeidsoriëntaties vier taakgerelateerde werkkenmerken opgenomen. We stellen vast dat het hoofdeffect van intrinsieke arbeidsoriëntaties niet verdwijnt of verzwakt na toevoeging van de vier werkkenmerken, maar het hoofdeffect van extrinsieke arbeidsoriëntatie wel. De werkkenmerken hebben geen mediatie-effect op de relatie tussen intrinsieke arbeidsoriëntatie en uitputting. Wanneer werknemers zich in werksituaties bevinden die naar de vier onderzochte werkkenmerken zeer sterke gelijkenissen vertonen, geraken ze minder snel uitgeput naarmate ze sterker intrinsiek georiënteerd zijn. Hun mate van extrinsieke arbeidsoriëntatie heeft verder geen effect op het niveau van emotionele uitputting.

De werkkenmerken leveren een belangrijke bijdrage aan de verklaring van verschillen tussen werknemers in emotionele uitputting. De totale verklaarde variantie van model 2 stijgt tot $14 \%$. De werkkenmerken vertonen een hoofdeffect conform de in hypothese 1 veronderstelde richting: de werkeisen hebben een positief effect, de O-HB een negatief effect op uitputting.

Tabel 3 Hiërarchische regressieanalyse met emotionele uitputting als afhankelijke: moderatie-effecten (TAS 2002)

\begin{tabular}{|c|c|c|c|}
\hline & \multicolumn{3}{|c|}{ Emotionele uitputting } \\
\hline & Model I & Model 2 & Model 3 \\
\hline Onderwijsniveau & $.04 *$ & $.05^{* *}$ & $.05 * *$ \\
\hline Leeftijd & ns & ns & ns \\
\hline Aantal contracturen & $.10^{* *}$ & $.10^{* *}$ & $.10^{* *}$ \\
\hline Geslacht & ns & ns & ns \\
\hline Werkdruk & $.31^{* *}$ & $.31 * *$ & $.31^{* *}$ \\
\hline Complexiteit & $.09 * *$ & $.09 * *$ & $.09 * *$ \\
\hline Autonomie & $.12^{* *}$ & $.12^{* *}$ & $.12^{* *}$ \\
\hline Ontwikkelingsmogelijkheden & $.15^{* *}$ & $.14 * *$ & $.14^{* *}$ \\
\hline Intrinsieke oriëntatie & & $.05 * *$ & $.06^{* *}$ \\
\hline Extrinsieke oriëntatie & & ns & ns \\
\hline Intrinsiek $x$ extrinsiek & & ns & ns \\
\hline Werkdruk $\mathrm{x}$ intrinsieke oriëntatie & & & $.04 *$ \\
\hline Complexiteit $\mathrm{x}$ intrinsieke oriëntatie & & & ns \\
\hline Autonomie $\mathrm{x}$ intrinsieke oriëntatie & & & $.04 *$ \\
\hline $\begin{array}{l}\text { Ontwikkelingsmogelijkheden } \mathrm{x} \text { intrinsieke } \\
\text { oriëntatie }\end{array}$ & & & $.04 *$ \\
\hline Werkdruk x extrinsieke oriëntatie & & & $.04 *$ \\
\hline Complexiteit $\mathrm{x}$ extrinsieke oriëntatie & & & ns \\
\hline Autonomie $\mathrm{x}$ extrinsieke oriëntatie & & & ns \\
\hline $\begin{array}{l}\text { Ontwikkelingsmogelijkheden } x \text { extrinsieke } \\
\text { oriëntatie }\end{array}$ & & & ns \\
\hline Constante & 2.61 & 2.60 & 2.64 \\
\hline Model & 74.69 & 55.13 & 33.61 \\
\hline $\begin{array}{l}\text { Totaal verklaarde variantie (Adj. } R \\
\text { kwadraat) }\end{array}$ & .141 & .145 & .146 \\
\hline
\end{tabular}

$* * \mathrm{p}<.01, * \mathrm{p}<.05$

In tabel 3 zijn de resultaten weergegeven van de regressieanalyse met uitputting als afhankelijke waarbij in model 1 de sociaaldemografische en werkkenmerken zijn opge- 
nomen. In model 2 zijn vervolgens de beide arbeidsoriëntaties en hun interactieterm toegevoegd. Aan de sterkte, richting of significantie van de hoofdeffecten van de werkkenmerken verandert niets. Er is dus geen mediatie-effect van intrinsieke arbeidsoriëntatie op de relatie tussen werkkenmerken en uitputting (vergelijk Xanthopoulou et al., 2007).

Figuur 2 Modererend effect van extrinsieke (boven) en intrinsieke (onder) arbeidsoriëntatie op de relatie tussen werkdruk en emotionele uitputting

\section{Emotionele uitputting}

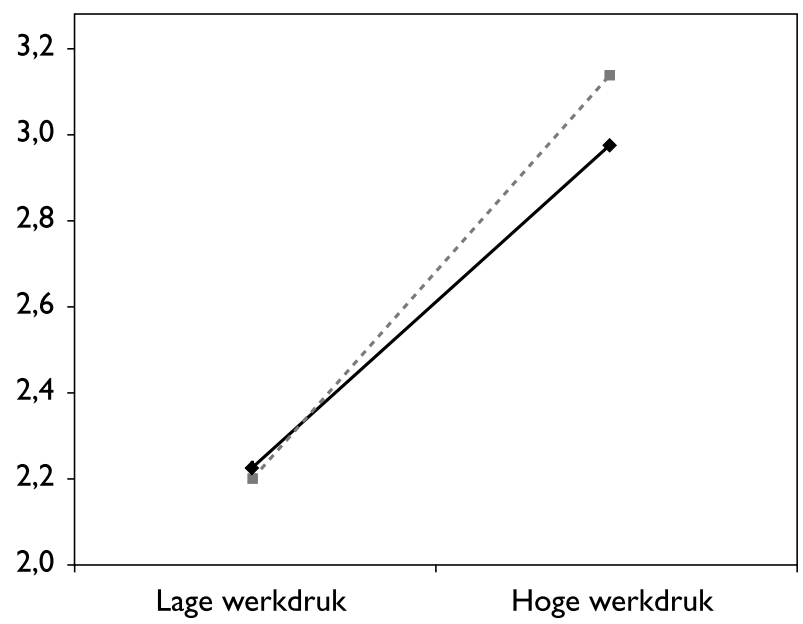

$\longrightarrow$ Lage extrinsieke oriëntatie

- - - - Hoge extrinsieke oriëntatie

\section{Emotionele uitputting}

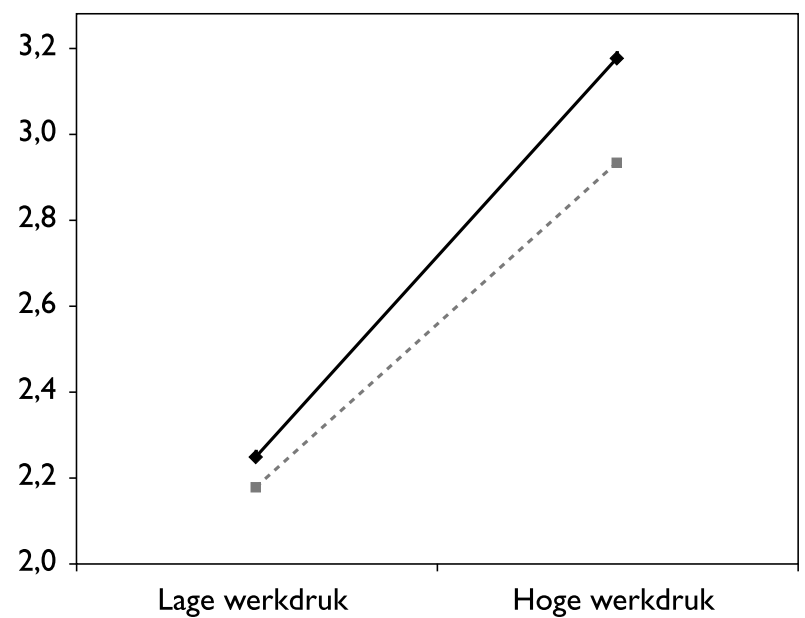

$\rightarrow-$ Lage intrinsieke oriëntatie

---- Hoge intrinsieke oriëntatie 
Met het oog op het toetsen van de hypothesen 3 en 4 zijn vervolgens in model 3 de interacties tussen de beide arbeidsoriëntaties en de werkkenmerken toegevoegd. Zowel intrinsieke als extrinsieke arbeidsoriëntatie heeft een significant modererend effect op de relatie tussen werkdruk en uitputting. In figuur 2 is dat interactie-effect grafisch weergegeven. Een sterke intrinsieke arbeidsoriëntatie verzwakt/buffert het positieve effect van hoge werkdruk op uitputting (bevestiging van hypothese 3 ). Een sterke extrinsieke arbeidsoriëntatie versterkt het positieve effect van hoge werkdruk op uitputting. Beide arbeidsoriëntaties blijken een rol te spelen in het stressproces: intrinsieke arbeidsoriëntatie als buffer in het uitputtingseffect van hoge werkeisen, extrinsieke arbeidsoriëntatie als versterker daarvan. Naarmate werknemers meer extrinsiek georiënteerd zijn, leidt een toename in de werkdruk tot een sterkere toename van de emotionele uitputting. Naarmate werknemers meer intrinsiek georiënteerd zijn, leidt een toename in de werkdruk tot een minder sterke toename van de emotionele uitputting. Hypothese 3 wordt echter slechts gedeeltelijk bevestigd. Intrinsieke arbeidsoriëntatie heeft geen significant modererend effect op de relatie tussen complexiteit (de andere werkeis) en uitputting. Mogelijk is dat te wijten aan het 'dubbelzinnige' karakter van het werkkenmerk complexiteit, dat zich nu eens als een werkeis, dan weer als een OHB 'gedraagt' (zie Van Ruysseveldt et al., 2008).

Ten slotte heeft intrinsieke arbeidsoriëntatie ook een significant modererend effect op de relatie tussen autonomie en uitputting en op de relatie tussen ontwikkelingsmogelijkheden en uitputting. Zoals verwacht versterkt een intrinsieke arbeidsoriëntatie het negatieve effect van de O-HB op uitputting (hypothese 4). Naarmate werknemers meer intrinsiek georiënteerd zijn, leidt de aanwezigheid van een hoge mate van autonomie en veel ontwikkelingsmogelijkheden tot een steilere daling van de emotionele uitputting (zie figuur 3). Werknemers met een hoge intrinsieke arbeidsoriëntatie zijn beter in staat de beschikbare O-HB waar te nemen en benutten deze beter in het omgaan met hoge werkeisen.

Het voorafgaande levert empirische steun voor de activeringsthese: $\mathrm{P}-\mathrm{HB}$, zoals intrinsieke arbeidsoriëntatie, leiden tot een effectievere benutting van de beschikbare $\mathrm{O}$ HB. Dat wordt nog eens onderstreept in de figuren $4 \mathrm{a}$ en $4 \mathrm{~b}$. In het omgaan met hoge werkdruk is autonomie in te zetten als een bufferende hulpbron: bij een hoge werkdruk leidt een toename van de autonomie tot verminderde uitputting. Uit figuur 4 onder blijkt dat werknemers met een lage intrinsieke oriëntatie niet in staat blijken deze bufferende 'voordelen' van hoge autonomie bij matige en hoge werkdruk effectief te benutten. Werknemers met een hoge intrinsieke arbeidsoriëntatie slagen er wél in de beschikbare autonomie in het werk bij hoge werkdruk te benutten als buffer (figuur 4 boven). Die bufferende werking van autonomie treedt voor sterk intrinsiek georiënteerden overigens op bij alle niveaus van werkdruk. Voor ontwikkelingsmogelijkheden is eenzelfde effect gevonden. 
Figuur 3 Modererend effect van intrinsieke arbeidsoriëntatie op de relatie tussen ontwikkelingsmogelijkheden (boven)/autonomie (onder) en emotionele uitputting

\section{Emotionele uitputting}

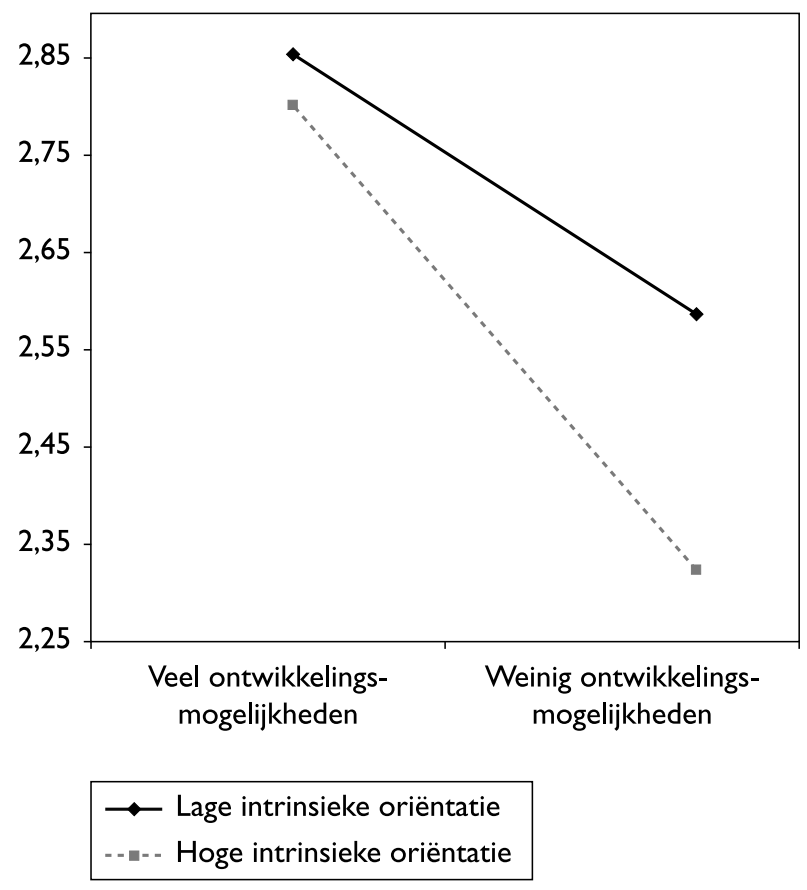

\section{Emotionele uitputting}

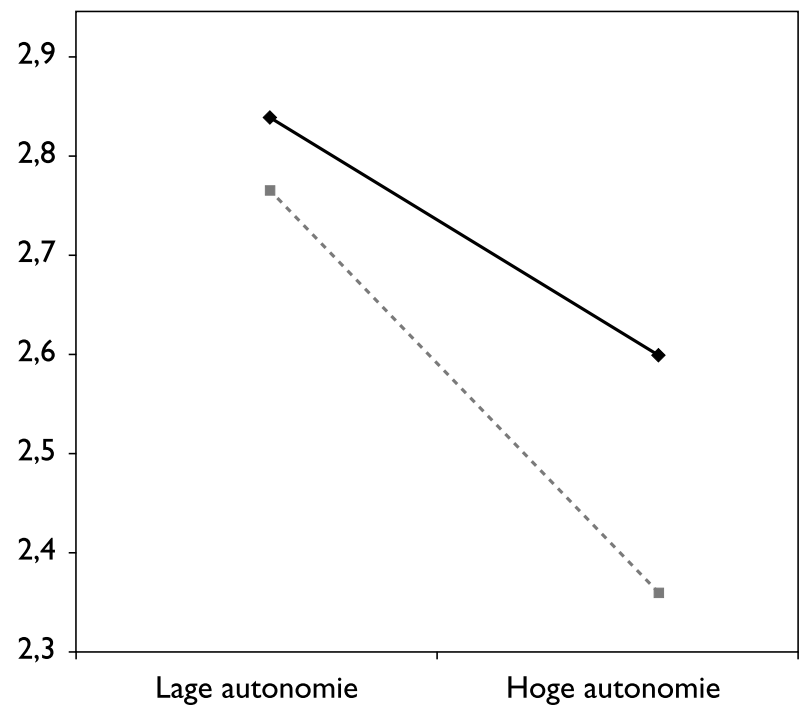

$\rightarrow$ Lage intrinsieke oriëntatie

-..- - Hoge intrinsieke oriëntatie 
Figuur 4 Het effect van autonomie op de relatie tussen werkdruk en emotionele uitputting voor werknemers met een hoge (boven) en een lage (onder) intrinsieke arbeidsoriëntatie

\section{Emotionele uitputting}

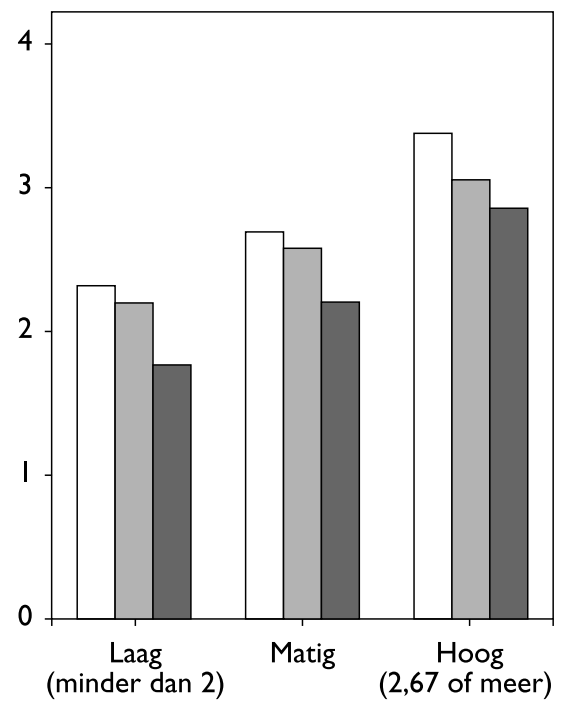

\section{Werkdruk}

\section{Emotionele uitputting}

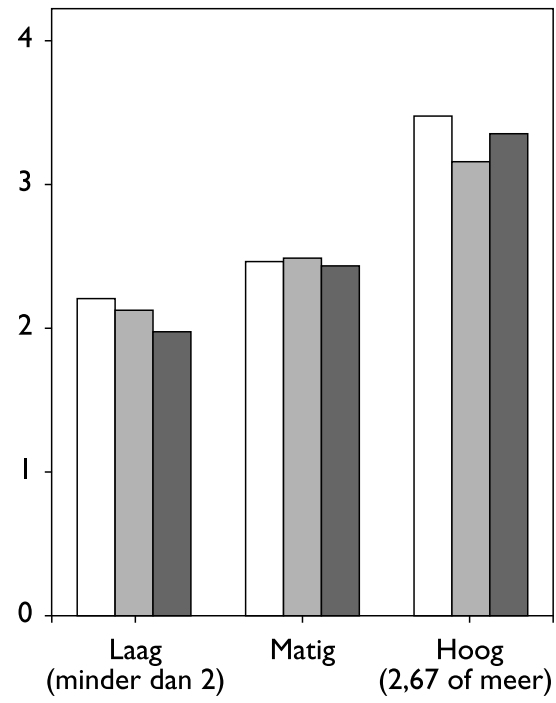

Werkdruk
Autonomie
$\square$ Laag
$\square$ Matig
$\square$ Hoog

\section{Autonomie \\ $\square$ Laag \\ $\square$ Matig \\ $\square$ Hoog}




\section{Samenvatting en discussie}

De onderzoeksresultaten leveren empirische steun voor de gestelde hypothesen. De werkkenmerken zijn de belangrijkste voorspellers van uitputtingsverschijnselen en leveren veruit de grootste bijdrage aan het verklaren van verschillen tussen individuele werknemers (H1). Gecontroleerd voor de sociaaldemografische en werkkenmerken heeft een intrinsieke arbeidsoriëntatie een significant negatief hoofdeffect op uitputting (H2). Dit betekent dat werknemers met vergelijkbare sociaaldemografische kenmerken en werkkenmerken minder snel uitgeput geraken naarmate ze sterker intrinsiek georiënteerd zijn. Deze bevindingen zijn in overeenstemming met de onderzoeksresultaten van Knoop (2001) en Baker (2004).

Ook de veronderstelde moderatie-effecten zijn significant. Een intrinsieke arbeidsoriëntatie buffert het positieve hoofdeffect van werkdruk (maar niet van complexiteit) op uitputting (H3). En een intrinsieke arbeidsoriëntatie versterkt het negatieve hoofdeffect van autonomie en ontwikkelingsmogelijkheden op uitputting (H4). Dat laatste gegeven levert een interessante toevoeging op aan het JD-R-model. Daarin is dit versterkend effect van $\mathrm{P}-\mathrm{HB}$ op de relatie tussen $\mathrm{O}-\mathrm{HB}$ en uitputting niet gehypotheseerd (Xanthopoulou et al., 2007).

Nog twee andere vaststellingen zijn vermeldenswaard. Ten eerste blijkt een extrinsieke arbeidsoriëntatie het positieve hoofdeffect van werkdruk op uitputting te versterken. Ten tweede zijn in de analyses geen indicaties gevonden voor een mediatie-effect van intrinsieke arbeidsoriëntatie op de relatie tussen werkkenmerken en uitputting (zoals voor andere persoonsgebonden kenmerken wel is gevonden door Xanthopoulou et al. (2007). Het hoofdeffect van intrinsieke arbeidsoriëntatie op uitputting blijft significant na toevoeging van de werkkenmerken. Er treedt geen mediatie-effect op, zoals onder meer is verondersteld door Warr (1994) en gevonden door Judge et al. (2000).

Samenvattend kunnen we besluiten dat een intrinsieke arbeidsoriëntatie voldoet aan de kenmerken van een P-HB: er is een direct negatief effect op uitputting, er is een bufferend effect op de relatie tussen werkdruk en uitputting, en er is een versterkend effect op de bufferende werking van de O-HB op uitputting.

\section{Implicaties voor theorie en onderzoek}

Het hier gehanteerde onderzoeksmodel is theoretisch gefundeerd en bij de integratie van persoonsgebonden kenmerken in het 'werkkenmerken'-model is mede de praktische relevantie voor ogen gehouden. In plaats van de (intuïtieve) toevoeging van persoonsgebonden kenmerken met het oog op het opdrijven van de totale verklaarde variantie (de wetenschappelijke drijfveer), ligt de uitdaging voor onderzoekers eerder in het opsporen van die persoonsgebonden kenmerken die zich laten kwalificeren als een P$\mathrm{HB}$ (de pragmatische drijfveer). Meerdere persoonsgebonden kenmerken zorgen voor een toename van de verklaringskracht van stressmodellen, maar vooral die kenmerken zijn belangrijk die zich 'gedragen' als een P-HB. Dat is het geval wanneer deze persoonsgebonden kenmerken een negatief hoofdeffect hebben op uitputtingsverschijnselen, een buffer vormen tegen de impact van hoge werkeisen en het effect van de O-HB versterken. Het is de vraag of andere 'prominente' persoonsgebonden kenmerken uit 
het stressonderzoek, zoals core self-evaluations, optimisme, self-efficacy en self-esteem, voldoen aan de criteria van $\mathrm{P}-\mathrm{HB}$.

Het verloop van de door ons gevonden moderatie-effecten laat bovendien toe het interventiedilemma te overstijgen waarvoor de fitmodellen zich geplaatst zien (zie inleiding). Fitmodellen voorspellen dat de uitputting het hoogste niveau bereikt bij een misfit, bijvoorbeeld ingeval een lage autonomie en weinig ontwikkelingsmogelijkheden samengaan met een sterke intrinsieke arbeidsoriëntatie. Onze resultaten wijzen echter uit dat bij een lage mate van autonomie en weinig ontwikkelingsmogelijkheden het niveau van intrinsieke arbeidsoriëntatie nauwelijks een invloed heeft (zie figuur 3 ). Een sterke intrinsieke arbeidsoriëntatie heeft wel een effect in een werksituatie met veel autonomie en ontwikkelingsmogelijkheden: ze 'activeert' dan de beschikbare OHB. Dat wil zeggen: de intrinsieke arbeidsoriëntatie leidt ertoe dat werknemers ook daadwerkelijk gebruik gaan maken van hun autonomie en ontwikkelingsmogelijkheden zodat ze hun werkomgeving en taakeisen beter kunnen beheersen.

Een aantal veronderstellingen en mechanismen in het hier toegepaste onderzoeksmodel blijft evenwel nog onvoldoende onderbouwd. Verder onderzoek op dit vlak is gewenst. Ten eerste is meer inzicht vereist in de samenhang tussen O-HB en P-HB. De vraag is welke mechanismen ervoor zorgen dat de O-HB 'geactiveerd' worden door de P-HB. Met betrekking tot intrinsieke arbeidsoriëntatie opperen we in dat verband de volgende mogelijkheden. Ten eerste zoeken en vinden personen met een sterke intrinsieke arbeidsoriëntatie complexer en uitdagender werk, dat wil zeggen: werk met veel autonomie, hoge kwalitatieve taakdoelstellingen en ontwikkelingsmogelijkheden (het zelfselectiemechanisme). Ten tweede zijn intrinsiek georiënteerde werknemers beter in staat om de mogelijkheden tot autonomie en persoonlijke ontwikkeling die in de werksituatie beschikbaar zijn, op te merken en te framen (het perceptiemechanisme). Daarmee is - ten derde - een belangrijk gevolg verbonden: omdat men de beschikbare mogelijkheden beter waarneemt, gaat men ze ook effectiever en optimaler benutten (het benuttingsmechanisme). Ten vierde is denkbaar dat intrinsiek georiënteerde werknemers een nog proactievere rol spelen in het tot stand brengen van bepaalde kenmerken van de werksituatie. Wellicht zijn ze meer geneigd inspanningen te leveren om de autonomie en ontwikkelingsmogelijkheden in het werk te bevorderen, ze zelfs af te dwingen of op eigen kracht tot stand te brengen (het productiemechanisme). Dat laatste is conform de COR-theorie van Hobfoll (2002): personen hanteren de beschikbare $\mathrm{P}-\mathrm{HB}$ om meer $\mathrm{O}-\mathrm{HB}$ te verwerven.

Ten tweede is meer inzicht gewenst in de veronderstelde wederkerigheid in de relatie tussen werkkenmerken en persoonsgebonden kenmerken. Zoals anderen (Kohn \& Schooler, 1982; Xanthopoulou et al., 2007) hebben we die wederkerigheid als gegeven geponeerd. Maar de wetenschappelijke implicaties daarvan zijn onduidelijk. In dit verband zou meer onderzoek kunnen worden gedaan naar bijvoorbeeld het optreden van zogenoemde gain-loss-spirals (zie Hobfoll, 2002). Uiteraard dient hierbij een longitudinaal of (quasi-)experimenteel onderzoeksdesign te worden gehanteerd. Een dergelijk design kan een beter inzicht opleveren in de richting en causaliteit van de verbanden tussen werkkenmerken, persoonsgebonden kenmerken en werkuitkomsten. 


\section{Implicaties voor de interventiepraktijk}

Het is van groot belang te onderstrepen dat de werkkenmerken de belangrijkste voorspellers van uitputting zijn (zie ook Schouteten, 2001). Bij het terugdringen van uitputtingsproblemen zijn in de eerste plaats interventies in het werk zelf noodzakelijk, en dan vooral in de werkdruk (zie ook Van Ruysseveldt et al., 2008). In die zin heeft het in de inleiding beschreven interventiedilemma een 'academisch' karakter.

Toch valt op dat de preventie- en interventiepraktijk haar pijlen nog vaak richt op de persoon. Er kan bijvoorbeeld worden gedacht aan cursussen ter bevordering van de self-efficacy of mindfullness tot en met cursussen voor het aanleren van relaxatietechnieken en het oefenen van een optimalere ademhalingsbeheersing. Onduidelijk is of en in welke mate dergelijke trainingen het gewenste effect bereiken. Op basis van de onderzoeksresultaten valt althans te besluiten dat trainingen die zich richten op persoonsgebonden kenmerken die het karakter van een P-HB hebben, het meest effectief zullen zijn. De inspanningen van onderzoekers en verantwoordelijken uit de interventiepraktijk zouden meer kunnen worden gericht op het opsporen en ontwikkelen of bijsturen van die persoonsgebonden kenmerken die functioneren als echte 'hulpbronnen'. Voor (her)ontwerpers van organisatieprocessen en werkplekken geldt dat het beschikbaar stellen van O-HB weliswaar van groot belang is, maar dat daarnaast het bevorderen van het daadwerkelijk door de werknemer benutten van de beschikbaar gestelde $\mathrm{O}-\mathrm{HB}$, niet uit het oog mag worden verloren.

Ons onderzoek bevestigt dat werknemers die groot belang hechten aan het hebben van inhoudelijk interessant, uitdagend werk met veel persoonlijke ontwikkelingsmogelijkheden, beter weten om te gaan met veeleisend werk en weerbaarder zijn tegen de negatieve gevolgen van uitputtend werk. Ze zijn ook beter in staat de beschikbare hulpbronnen te benutten voor het realiseren van de taakdoelen. Een dergelijke arbeidsoriëntatie is echter het gevolg van een persoonlijk waarderingsproces op basis van maatstaven die mensen in volle vrijheid (moeten kunnen) kiezen. Daarom zijn interventies van 'derde partijen' zoals de overheid of organisaties op dit specifieke terrein onwenselijk - want een inbreuk op de persoonlijke levenssfeer - en wellicht ook ineffectief. De praktische relevantie van dit onderzoek betreft dan ook in de eerste plaats enige mate van bewustwording bij de betrokken werknemers zelf: het ontwikkelen van een zekere gevoeligheid en waardering voor taakintrinsieke aspecten biedt voordelen in het beheersen van de uitputtingsgevolgen van veeleisend werk.

\section{Noten}

1 In het theoretische deel van dit artikel is meestal de algemene term 'stress' gehanteerd, als een verzamelnaam waarin de meeste in onderzoek toegepaste operationaliseringen voor negatieve werkuitkomsten zoals emotionele uitputting, psychische vermoeidheid, spanningsen gezondheidsklachten kunnen worden ondergebracht. Bij de beschrijving van de onderzoeksresultaten is consequent gekozen voor de term 'emotionele uitputting', omdat het stressniveau bij werknemers aan de hand van de schaal emotionele uitputting (subschaal van de UBOS) is gemeten.

2 In de literatuur wordt naast arbeidsoriëntaties ook gesproken over work values of werkwaarden (zie bijv. Warr, 1994; Knoop, 1995, 2001; Evers, Ybema \& Smulders, 2006). 


\section{Literatuur}

Achterberg, P., Houtman, D. \& Jetten, B. (2003). Arbeidstevredenheid: een aanpassingsfenomeen? Tijdschrift voor Arbeidsvraagstukken, 19, 214-227.

Baker, S. (2004). Intrinsic, extrinsic, and amotivational orientations: their role in university adjustment, stress, well-being, and subsequent academic performance. Current Psychology, 23, 189-202.

Bakker, A. \& Demerouti, E. (2007). The Job Demands - Resources Model: state of the art. Journal of Managerial Psychology, 22, 309-328.

Bakker, A., Schaufeli, W. \& Demerouti, E. (1999). Werkstressoren, energiebronnen, en burnout: het WEB-model. In: J. Winnubst, F. Schuur \& J. Dam (red.). Praktijkboekgezond werken (pp.119). Maarssen: Elsevier.

Berting, J. \& Sitter, L. de (1971). Arbeidssatisfactie. Theorie-methodiek-feiten. Assen: Van Gorcum.

Berting, J. \& Sitter, L. de (red.) (1968). Arbeidsvoldoening en arbeidsbeleid. Utrecht: Spectrum.

Boer, F., Jonge, J. de \& Hamers, J. (2003). De relatie van werkkenmerken en bijpassende persoonskenmerken met psychisch welbevinden. Gedrag \& Organisatie, 16, 221-236.

Bourdeaud'hui, R. \& Vanderhaeghe, S. (2008). Arbeidsethos en arbeidsoriëntaties op de Vlaamse arbeidsmarkt: loontrekkenden en zelfstandige ondernemers. Brussel: SERV.

Demerouti, E., Nachreiner, F., Bakker, A. \& Schaufeli, W. (2001). The Job Demands-Resources Model of Burnout. Journal of Applied Psychology, 86, 499-512.

Evers, M., Ybema, J.F. \& Smulders, P. (2006). Arbeidstevredenheid: gevolg van werkkenmerken, werkwaarden of beide? Gedrag \& Organisatie, 19, 37-48.

French, J., Kaplan, R. \& Harrison, R. (1982). The mechanisms of job stress and strain. Chichester: Wiley.

Goudswaard, A., Dhondt, S. \& Kraan, K. (1998). Flexibilisering en arbeid in de informatiemaatschappij; werknemersvragenlijst, bestemd voor werknemers en bedrijven die deelnemen aan het SZWWerkgeverspanel 1998, Hoofddorp: TNO Arbeid.

Hobfoll, S. (1989). Conservation of resources. A new attempt at conceptualizing stress. American Psychologist, 44, 513-524.

Hobfoll, S. (2002). Social and psychological resources and adaptation. Review of General Psycho$\operatorname{logy}, 6,307-324$.

Houkes, I., Janssen, P., Jonge, J. de \& Bakker, A. (2003). Personality, work characteristics, and employee well-being: a longitudinal analysis of additive and moderating effects. Journal of Occupational Health Psychology, 8, 20-38.

Houtman, I., Goudswaard, A., Dhondt, S., Grinten, M. van der, Hildebrandt, V. \& Kompier, M. (1995). Evaluatie van de monitorstudie naar stress en lichamelijke belasting. Den Haag: VUGA.

Judge, T., Bono, J. \& Locke, E. (2000). Personality and job satisfaction: the mediating role of job characteristics. Journal of Applied Psychology, 85, 237-249.

Judge, T., Locke, E., Durham, C. \& Kluger, A. (1998). Dispositional effects on job and life satisfaction: the role of core evaluations. Journal of Applied Psychology, 83, 17-34.

Karasek, R. (1979). Job demands, job decision latitude, and mental strain: implications for job redesign. Administrative Science Quarterly, 24, 285-307.

Karasek, R. \& Theorell, T. (1990). Healthy work: stress, productivity and the reconstruction of working life. New York: Basic Books.

Knoop, R. (2001). Relieving stress through value-rich work. The Journal of Social Psychology, 134, 829-836.

Kohn, M. \& Schooler, C. (1982). Job conditions and personality: a longitudinal assessment of their reciprocal effects. American Journal of Sociology, 87, 1257-1286.

Lofquist, L. \& Dawis, R. (1969). Adjustment to work: a psychological view of man's problems in a work-oriented society. New York: Appleton-Century-Crofts.

Lu, L. (1999). Work motivation, job stress and employees' well-being. Journal of Applied Management Studies, 8, 61-72.

Schaufeli, W. \& Bakker, A. (2001). Werk en welbevinden. Naar een positieve benadering in de Arbeids- en gezondheidspsychologie. Gedrag en Organisatie, 14, 229-252.

Schaufeli, W. \& Bakker, A. (2004). Job demands, job resources, and their relationship with burnout and engagement: a multi-sample study. Journal of Organizational Behavior, 25, 293315.

Schaufeli, W. \& Dierendonck, D. van (2000). UBOS - De Utrechtse Burnout Schaal. Handleiding. Lisse: Zwets \& Zeitlinger. 
Schouteten, R. (2001). Balances in well-being at work. Measurements, determinants, and improvements of the quality of working life. Capelle a/d IJssel: Labyrinth Publications.

Smulders, P., Andries, F. \& Otten, F. (2001). Hoe denken Nederlanders over hun werk? Opzet, kwaliteit en eerste resultaten van de TNO Arbeidssituatie Survey. Hoofddorp: TNO Arbeid.

Taris, R. \& Feij, J. (2001). Longitudinal examination of the relationship between supplies-values fit and work outcomes. Applied Psychology: an International Review, 50, 52-80.

Van Hoof, J., Bruin, P., Schoemaker, M. \& Vroom, A. (2002). Werk(en) moet wel leuk zijn. Arbeidswensen van Nederlanders. Assen: Van Gorcum.

Van Ruysseveldt, J., Cambré, B., Depickere, A. \& Adiele, M. (2004). Door de bank genomen? Stress in de banksector. In: G. Van Hootegem \& B. Cambré (red.). Over werk( $t$ ) in de actieve welvaartstaat (pp. 189-204). Leuven: Acco.

Van Ruysseveldt, J. (2006). Psychische vermoeidheid en plezier in het werk bij Vlaamse werknemers. Tijdschrift voor Arbeidsvraagstukken, 22, 328-343.

Van Ruysseveldt, J., Smulders, P. \& Taverniers, J. (2008). De invloed van werkeisen en hulpbronnen op uitputting en bevlogenheid. Tijdschrift voor Arbeidsvraagstukken, 24, 225-242.

Van Steenkiste, M., Neyrinck, B., Niemec, P., Soenens, B., De Witte, H. \& Van den Broeck, A. (2007). On the relations among work value orientations, psychological need satisfaction and job outcomes: a self-determination theory approach. Journal of Occupational and Organizational Psychology, 80, 251-277.

Warr, P. (1994). A conceptual framework for the study of work and mental health. Work \& Stress, $8,84-97$.

Xanthopoulou, D., Bakker, A., Demerouti, E. \& Schaufeli, W. (2007). The role of personal resources in the job demands-resources model. International Journal of Stress Management, 14, 121141. 